\title{
AKTIVITAS POLISAKARIDA KRESTIN DARI EKSTRAK Coriolus versicolor TERHADAP PENINGKATAN ANTIBODI Mus musculus AKIBAT PAPARAN Mycobacterium tuberculosis
}

\author{
Sri Puji Astuti Wahyuningsih*, Amalia Nur Masitha, dan Dwi Winarni \\ Departemen Biologi, Fakultas Sains dan Teknologi, Universitas Airlangga \\ *E-mail: sripujiastuti@unair.ac.id
}

\begin{abstract}
This research aimed to know the bioactivity of polysaccharide krestin (PSK) with a different timing on formation of mice antibody exposed by Mycobacterium tuberculosis. Mycobacterium tuberculosis was used as infection agent that had an abilitiy to be imunogenic and to lead immune system responsses decreased. Polysaccharides krestin was used as immunopotentiator which had a role to activate macrophage and stimulate B cell in order to produce antibody. This research involved 30 adult female mice of Mus musculus strain $\mathrm{Balb} / \mathrm{C}$ in the age of 8-10 weeks and in the weight between of 30-40 g. Mice were divided into six groups, as follows: group K as a control, was added only aquades; group $K+$ as positive control, was added only PSK; group K-as negative control, was exposed by M. tuberculosis only; group P1 was added PSK before being exposed by M. tuberculosis; group P2 was added PSK after being exposed by M. tuberculosis; group P3 was added PSK before and after being exposed by M. tuberculosis. Polysaccharides krestin was added by gavage with single dose of $500 \mu \mathrm{g}$ and $M$. tuberculosis was exposed intraperitoneally with concentration of $5 \times 10^{8}$ bactery per $\mathrm{ml}$. The bioactivity of PSK was observed by formation antibody using indirect ELISA test. The results of research were the average of $O D$ value of $K$ group was 0,590 $\pm 0,042, K+$ group was $0.641 \pm 0.025, K$ - group was $1.044 \pm 0.054, P 1$ group was $1.032 \pm 0.125$, $P 2$ group was $1.127 \pm 0.042$, P 3 group was $1.230 \pm 0.097$. The conclusion of this research showed that the adding of PSK increased mice formation antibody. The time of adding before and after being exposed M. tuberculosis was the most potential to raise antibody production on mice.
\end{abstract}

Keywords: Mycobacterium tuberculosis, polysaccharide krestin (PSK), mice, antibody, indirect ELISA

\section{PENGANTAR}

Tuberkulosis (TB) paru adalah penyakit menular yang disebabkan oleh bakteri Mycobacterium tuberculosis (Alsagaff dan Mukty, 2002). Bakteri tersebut memasuki tubuh secara inhalasi, tertelan atau kontak langsung melalui kulit (Dzen dkk., 2003). Pada respons primer diperlukan waktu beberapa hari sebelum antibodi ditemukan dalam darah. Pada respons sekunder, kadar antibodi dalam darah meningkat tajam dan mencapai kadar maksimum yang jauh lebih tinggi dibanding dengan respons primer. Hal ini disebabkan adanya ekspansi sel memori (Baratawidjaja, 2006). Pada umumnya, reaksi daya tahan tubuh dapat menghentikan perkembangan bakteri TB. Namun, terdapat beberapa bakteri yang menetap sebagai bakteri persisten dan terkadang daya tahan tubuh tidak mampu menghentikan perkembangan bakteri tersebut. Akibatnya dalam beberapa bulan, seseorang akan menjadi penderita TB (Poeloengan dkk., 2009).

Menurut Alsagaff dan Mukty (2002), populasi M. tuberculosis terbagi menjadi populasi bakteri ekstraseluler dan intraseluler. Antibodi yang dihasilkan oleh sel B adalah komponen imun protektif terhadap bakteri ekstraseluler
(Baratawidjaja, 2006). Antibodi mempertahankan tubuh terhadap agen penyebab penyakit, yaitu langsung menyerang penyebab penyakit dan mengaktifkan sistem imun komplemen (Guyton and Hall, 1997).

Menurut Koendhori (2008), bakteri TB memiliki kemampuan hidup dan berkembang biak dalam makrofag (intraseluler) sehingga sulit dijangkau oleh antibodi. Sebagian besar bakteri dibunuh oleh makrofag. Bakteri ini juga mampu bertahan dalam makrofag dan memperbanyak diri dengan cepat.

Burgess (1995), respons terhadap bakteri intraseluler adalah respons imun seluler. Bakteri menginduksi sel $\mathrm{T}$ menjadi Th1 dan merangsang produksi antibodi oleh sel B yang memiliki sifat opsonin (Baratawidjaja, 2006). Opsonisasi antigen oleh antibodi meningkatkan fagositosis, memudahkan antigen presenting cell (APC) memproses dan menyajikan antigen kepada sel T, dan meningkatkan fungsi sel NK dalam mekanisme antibody dependent cytotoxicity (ADCC) (Kresno, 2001).

Beberapa peneliti menggunakan imunomodulator sebagai terapi tambahan penderita TB (Koendhori, 2008). Dasar pemikiran penggunaan imunomodulator bahwa dari sepertiga populasi manusia yang terpapar M. tuberculosis 
hanya sepersepuluhnya yang menjadi sakit. Hal ini menunjukkan sistem imun bekerja cukup efektif untuk melawan infeksi TB (Koendhori, 2008).

Terdapat banyak polisakarida terikat protein yang diisolasi dari jamur sebagai anti bakteri. Polisakarida krestin dari ekstrak Coriolus versicolor telah banyak digunakan sebagai obat penyakit tumor di Jepang (Ooi dan Liu, 2000; Sastroasmoro et al., 2004).

Bahan aktif dari PSK adalah $\beta$-glukan yang melimpah pada dinding sel jamur. Senyawa aktif $\beta$-glukan berhubungan dengan reseptor utama sistem imun yaitu dectin-1, toll like receptor-2/6 (TLR-2/6) dan complement receptor (CR3). Sel imun target $\beta$-glukan meliputi makrofag, neutrofil, monosit, sel NK dan sel dendritik. Sebagai konsekuensinya, respons imun spesifik dan non spesifik dapat dimodulasi $\beta$-glukan dan berperan dalam opsonin dan non-opsonin fagositosis (Chi-Fung et al., 2009).

Polisakarida krestin memiliki banyak aktivitas fisiologis meliputi imunopotensiasi dengan menginduksi sel makrofag dan limfosit $\mathrm{T}$, menginduksi produk sel seperti interleukin-6 (IL-6), interferon dan imunoglobulin-G. Selain memiliki kemampuan meningkatkan respons imun, PSK juga memiliki kemampuan dalam menekan respons imun (imunosupresi) karena dampak dari kemoterapi, radioterapi dan transfusi darah. Kemampuan PSK yang lain adalah meningkatkan nafsu makan dan fungsi hati, menenangkan sistem saraf pusat dan meningkatkan ambang batas sakit (Cui dan Chisti, 2003; Zhou et al., 2007). Selain itu, $\beta$-glukan meningkatkan produksi dari sitokin penting yaitu interleukin-2 (IL-2) yang menstimulasi diferensiasi dari sel B yang aktif (Vetvicka et al., 2002). Polisakarida krestin juga telah terbukti memiliki khasiat sebagai anti tumor dan anti kanker melalui mekanisme modifikasi respons biologis dengan pengaktifan sistem imun tubuh (Tsukagoshi et al., 1984).

Pemberian PSK sebelum paparan M. tuberculosis dapat berfungsi sebagai pencegahan (preventif) yaitu mendorong pembentukan antibodi sehingga antibodi yang semakin menurun pada penderita TB tidak terlalu drastis dan bisa di atasi dengan diberikannya kembali PSK sebagai pengobatan (kuratif) yang mendorong pembentukan lebih banyak antibodi. Hal ini didukung oleh pernyataan Pietro (2003) bahwa $\beta$-glukan lebih efektif untuk pencegahan dan pengobatan terhadap penyakit yang berhubungan dengan ketahanan sistem imun tubuh.

Penelitian ini adalah untuk mengetahui pengaruh pemberian polisakarida krestin (PSK) dari ekstrak Coriolus versicolor terhadap pembentukan antibodi pada mencit akibar akibat paparan M. tuberculosis.

\section{BAHAN DAN CARA KERJA}

\section{Persiapan Hewan Coba}

Mencit diaklimasi selama satu minggu dan dikelompokkan menjadi enam, yaitu K (hanya diberi akuades), $\mathrm{K}$ - (paparan M. tuberculosis saja), $\mathrm{K}+$ (diberi PSK saja), P1 (pemberian PSK sebelum paparan M. tuberculosis), P2 (pemberian PSK setelah paparan M. tuberculosis), P3.(pemberian PSK sebelum dan sesudah paparan M. tuberculosis). Pakan berupa pelet dan minum secara ad libitum.

\section{Koleksi dan Pembuatan Serbuk Jamur Coriolus versicolor}

Jamur Coriolus versicolor dikoleksi dari daerah Lamongan, Mojokerto, Banyuwangi, dan Blitar. Jamur diidentifikasi, dikering anginkan dan dihaluskan sehingga terbentuk serbuk kasar jamur.

\section{Isolasi dan Pengukuran Kadar PSK}

Isolasi PSK dilakukan menurut metode Cui dan Chisti (2003) dan Cui et al. (2007) yang dimodifikasi oleh Wahyuningsih dkk. (2007). Kadar PSK ditentukan dengan metode phenol-sulphuric acid assay. Dosis PSK yang digunakan adalah $500 \mathrm{mg} / \mathrm{ml}$ per ekor.

\section{Pemberian PSK dan Paparan M. tuberculosis pada Hewan Coba}

Pemberian PSK dilakukan selama 7 hari berturut-turut sesuai kelompoknya. Paparan M. tuberculosis dilakukan dua kali dengan selang waktu satu minggu melalui intraperitoneal. Jumlah bakteri adalah 0,5 Mc Farland setara dengan $1,5 \times 10^{8} \mathrm{CFU} / \mathrm{ml}$.

\section{Pengambilan Serum}

Darah diambil melalui jantung (intracardiac) sebanyak $1 \mathrm{ml}$. Darah dibiarkan dalam posisi miring pada suhu kamar selama dua jam. Selanjutnya disentrifugasi kecepatan 3000 rpm, 10 menit pada suhu $4^{\circ} \mathrm{C}$ hingga terbentuk dua fase, bagian atas berwarna kuning (serum) dan bagian bawah berwarna merah (darah). Serum dipisahkan dari darah dan dikoleksi.

\section{Enzyme-Like Immunosrbent Assay (ELISA)}

Deteksi antibodi melalui nilai optical density (OD) menggunakan metode indirect ELISA. Bakteri M. tuberculosis $100 \mu \mathrm{l}$ yang telah disonikasi di coating dalam cawan plate 96 sumuran dan diinkubasi pada suhu $4^{\circ} \mathrm{C}, 24 \mathrm{jam}$. Sejanjutnya dilakukan blocking dengan BSA $10 \% 200 \mu \mathrm{l}$ dan diinkubasi 15 menit pada suhu kamar. 
Setiap sumuran ditambahkan $100 \mu \mathrm{l}$ antibodi primer dalam PBS pada suhu kamar 1 jam. Kemudian dicuci dengan 100 $\mu 1$ larutan pencuci yang diulang tiga kali. Setiap sumuran ditambahkan $100 \mu$ l konjugat IgG goat anti mouse dengan konsentrasi $1 \mu \mathrm{g} / \mathrm{ml}$ dan diinkubasi 1 jam pada suhu kamar.

Kemudian diicuci dengan $100 \mu 1$ larutan pencuci yang diulang tiga kali. Setiap sumuran ditambahkan $100 \mu 1$ substrat yang terdiri dari ABTS dan larutan peroxidase $\mathrm{B}$ dengan perbandingan 1:1. Setiap sumuran ditambahkan $100 \mu 1$ laruran penghenti. Nilai OD antibodi diukur dengan microplate reader pada panjang gelombang $405 \mathrm{~nm}$ (Wahyuningsih et al., 2007).

\section{Analisis Data}

Data diuji dengan Kolmogorov-Smirnov dan uji homogenitas variansi. Selanjutnya dianalisis dengan ANOVA satu arah dan BNT pada taraf kepercayaan 5\% $(\alpha=0,05)$.

\section{HASIL}

Kadar antibodi sebanding dengan nilai optical density (OD). Semakin tinggi nilai OD semakin besar juga kadar antibodinya. Antibodi mencit yang terbentuk sebagai gambaran respons imun spesifik akibat paparan M. tuberculosis ditunjukkan pada Tabel dan Gambar 1 .

Hasil ELISA berupa reaksi warna yang berwarna hijau kebiruan. Warna ini diperoleh setelah terjadi ikatan yang lengkap antara antigen dengan antibodi primer dan antibodi sekunder yang berlabel enzim. Saat dItambahkan substrat maka terjadi perubahan warna dari jernih menjadi hijau kebiruan sehingga nilai OD dapat dibaca.

Hasil penelitian menunjukkan bahwa rerata nilai OD pada kelompok kontrol $(\mathrm{K})$ sebesar 0,590 $\pm 0,042$, kelompok kontrol positif $(\mathrm{K}+)$ sebesar 0,641 $\pm 0,025$, kelompok kontrol negatif (K-) sebesar 1,044 $\pm 0,054$, kelompok P1 sebesar 1,032 $\pm 0,125$, kelompok P2 sebesar $1,127 \pm 0,042$, kelompok P3 sebesar 1,230 $\pm 0,097$.

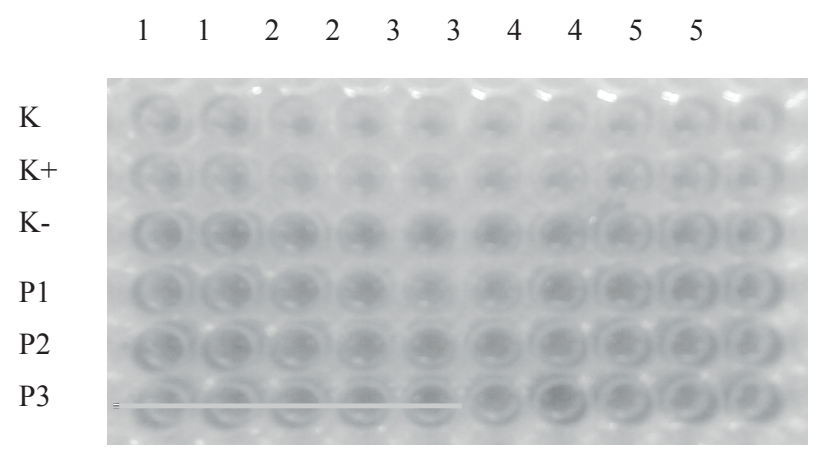

Gambar 1. Hasil uji ELISA. Pengujian dilakukan secara duplo, (K) kontrol; (K+) kontrol positif; (K-) kontrol negatif; (P1) perlakuan 1, pemberian PSK sebelum paparan M. tuberculosis; (P2) pemberian PSK setelah paparan M. tuberculosis; (P3) pemberian PSK sebelum dan setelah paparan $M$. tuberculosis.

Berdasarkan uji Kolmogorov-Smirnov didapatkan tingkat signifikansi 0,125 , menunjukkan bahwa sebaran data berdistribusi normal. Berdasarkan hasil uji homogenitas diperoleh tingkat signifikansi 0,135 , menunjukkan bahwa sebaran data memiliki variansi yang homogen, sehingga dilanjutkan uji ANOVA satu arah guna mengetahui pengaruh pemberian perlakuan pada masing-masing kelompok. Hasil uji ANOVA didapatkan tingkat signifikansi 0,000. Hal tersebut menunjukkan ada pengaruh pemberian PSK terhadap peningkatan respons imun berupa pembentukan antibodi mencit akibat paparan M. tuberculosis.

Data selanjutnya diuji BNT untuk mengetahui beda signifikan rerata antar dua kelompok variasi perlakuan. Hasil uji menunjukkan rerata nilai OD antibodi antara kelompok K dengan kelompok K-, P1, P2, P3, berbeda signifikan dengan tingkat signifikansi 0,000 , sedangkan kelompok K dengan kelompok $\mathrm{K}+$ tidak berbeda signifikan dengan tingkat signifikansi 0,292 . Rerata nilai OD antibodi pada kelompok $\mathrm{K}+$ berbeda signifikan dengan kelompok $\mathrm{K}-, \mathrm{P} 1, \mathrm{P} 2, \mathrm{P} 3$ dengan tingkat signifikansi 0,000, sedangkan kelompok $\mathrm{K}+$ tidak berbeda signifikan dengan kelompok K. Rerata nilai OD antibodi pada kelompok K- berbeda

Tabel 1. Rerata nilai OD dari antibodi pada serum mencit

\begin{tabular}{|c|c|c|c|c|c|c|}
\hline \multirow{2}{*}{ Kelompok } & \multicolumn{5}{|c|}{ Nilai OD pada ulangan ke- } & \multirow{2}{*}{ Rerata } \\
\hline & 1 & 2 & 3 & 4 & 5 & \\
\hline $\mathrm{K}$ & 0,662 & 0,595 & 0,569 & 0,571 & 0,557 & $0,590 \pm 0,042^{a}$ \\
\hline $\mathrm{K}+$ & 0,681 & 0,611 & 0,644 & 0,635 & 0,634 & $0,641 \pm 0,025^{a}$ \\
\hline $\mathrm{K}-$ & 1,134 & 1,047 & 1,039 & 1,004 & 0,997 & $1,044 \pm 0,054 b$ \\
\hline $\mathrm{P} 1$ & 1,057 & 1,089 & 0,810 & 1,106 & 1,101 & $1,032 \pm 0,125^{b}$ \\
\hline $\mathrm{P} 2$ & 1,194 & 1,108 & 1,142 & 1,108 & 1,085 & $1,127 \pm 0,042^{b}$ \\
\hline P3 & 1,153 & 1,211 & 1,246 & 1,390 & 1,153 & $1,230 \pm 0,097^{c}$ \\
\hline
\end{tabular}


signifikan dengan kelompok $\mathrm{K}$ dan $\mathrm{K}+$, dengan kelompok P3 berbeda signifikan sebesar 0,001. Kelompok K- tidak berbeda signifikan dengan kelompok P1 dengan tingkat sigfikansi 0,806, sedangkan dengan kelompok P2 tidak berbeda signifikan dengan tingkat signifikansi 0,087. Rerata nilai OD antibodi kelompok perlakuan P1 berbeda signifikan dengan kelompok $\mathrm{K}, \mathrm{K}+, \mathrm{P} 3$ dengan tingkat signifikansi 0,000. Kelompok P1 dengan kelompok K- tidak berbeda signifikan, dengan kelompok P2 tidak berbeda signifikan dengan tingkat signifikansi 0,053. Rerata nilai OD antibodi kelompok P2 berbeda signifikan dengan kelompok $\mathrm{K}$ dan $\mathrm{K}+$, dengan kelompok $\mathrm{P} 3$ berbeda signifikan sebesar 0,037 . Kelompok P2 tidak berbeda signifikan dengan kelompok K- dan P1. Rerata nilai OD antibodi kelompok P3 berbeda signifikan dengan seluruh kelompok perlakuan.

\section{PEMBAHASAN}

Nilai optical density hasil ELISA menunjukkan banyaknya ikatan antara antigen dan antibodi yang spesifik, semakin tinggi nilai OD menunjukkan semakin banyak substrat kromogenik 2,2"- azino - bis - (3-ethylbenzil thiazoline-6--sulfonate) (ABTS) yang dikatalis oleh enzim horseradish peroxidase sehingga menyebabkan perubahan warna menjadi hijau kebiruan. Enzim ini dapat bekerja jika terjadi ikatan yang lengkap antara antigen dengan antibodi primer dan antibodi sekunder (konjugat IgG goat anti mouse peroxidase). Semakin tinggi nilai OD menunjukkan semakin banyak antibodi yang berikatan dengan antigen, menunjukkan semakin tinggi pula kadar antibodi yang spesifik terhadap antigen M. tuberculosis yang terdapat pada serum mencit. Hal ini didukung oleh pernyataan Suwarno et al., (2008) dan Crowther (1995) bahwa aktivitas antigen dan antibodi dapat diekspresikan berdasarkan nilai OD yang terserap setelah penambahan substrat. Nilai absorbans dipakai sebagai ukuran langsung dari reaktivitas sampel. Pada penggunaan konjugat yang berlabel enzim horseradish peroxidase, semakin hijau warna yang dihasilkan akan menunjukkan semakin tinggi nilai OD yang terbaca dan semakin tinggi jumlah antibodi yang terdeteksi. Menurut Baratawidjaya (2006), perubahan warna yang terjadi sesuai dengan jumlah enzim yang diikat dan sesuai pula dengan kadar antibodi yang dicari.

Paparan bakteri M. tuberculosis dilakukan secara intraperitonal sebanyak dua kali dengan selang waktu satu minggu yaitu paparan pertama dilakukan pada hari ke-8 dan paparan kedua dilakukan pada hari ke-15. Hal ini didukung oleh Bellanti (1993) bahwa antibodi dapat dideteksi 10 sampai 14 hari sesudah paparan sel-sel bakteri. Paparan secara berulang dengan selang waktu tertentu akan meningkatkan respons imun hewan coba dengan cara menstimulir sejumlah klon sel B untuk menghasilkan antibodi dan sel memori. Pengulangan (booster) memberikan pengaruh pada sel memori untuk membelah dan berdiferensiasi menjadi sel plasma untuk memproduksi antibodi melalui kontak kedua dengan antigen yang sama sehingga antibodi yang dihasilkan semakin banyak. Hal ini didukung oleh pernyataan Artama (1992) dan Bellanti (1993) bahwa selama respons sekunder ini sel-sel imunokompeten lebih cepat mengenali antigen karena sudah terbentuk sel-sel memori terhadap antigen yang sama pada saat respons primer, sehingga pembentukan antibodi lebih cepat. Antibodi yang dominan pada respons primer adalah IgM sedangkan antibodi yang dominan pada respons sekunder adalah IgG. Menurut Howard et al. (2001), metode imunisasi yang paling tepat untuk mencit adalah secara intraperitonial. Hal ini didukung juga oleh Bellanti (1993), bahwa di daerah intraperitoneal banyak terdapat sel-sel imunokompeten yang berasosiasi dengan mukosa disebut sebagai mucous associated lymphoid tissue (MALT).

Menurut Alsagaff dan Mukty (2002), populasi M. tuberculosis terbagi menjadi populasi bakteri ekstraseluler dan populasi bakteri intraseluler. Hal ini didukung oleh Kresno (2001) bahwa M. tuberculosis merupakan bakteri yang mampu berkembang biak secara intraseluler. Antibodi yang dihasilkan oleh sel B adalah komponen imun protektif utama terhadap bakteri ekstraseluler yang menyingkirkan mikroba dan menetralisir toksinnya (Baratawidjaja, 2006). Menurut Koendhori (2008), M. tuberculosis sebagai penyebab penyakit TB merupakan bakteri patogen yang memiliki kemampuan hidup dan berkembang biak di dalam makrofag (intraseluler) sehingga sulit dijangkau oleh antibodi dalam sirkulasi, sehingga untuk eliminasinya memerlukan mekanisme selular.

Dalam melawan bakteri intraseluler dapat melalui dua jenis reaksi yaitu pembunuhan bakteri intraseluler yang difagosit oleh makrofag teraktivasi, dengan aktivasi makrofag terjadi melalui sitokin, khususnya IFN- $\gamma$, yang diproduksi oleh sel T. Cara kedua dengan lisis sel yang terinfeksi oleh sel T CD8+. Protein bakteri intraseluler dapat merangsang sel T CD4+ (melalui kompleks antigen MHC kelas II) maupun sel T CD8+ (melalui kompleks antigen MHC kelas I). Bakteri intraseluler menginduksi perkembangan sel T menjadi fenotip sel Th1, karena bakteri ini merangsang produksi interleukin-2 (IL-2) oleh makrofag dan IFN- $\gamma$ oleh sel NK, kedua jenis sitokin ini meningkatkan perkembangan sel Th1 (CD4+). Sel Th1 memproduksi IFN- $\gamma$ yang mengaktifkan makrofag 
untuk memproduksi ROI dan enzim-enzim yang dapat membunuh bakteri. Interferon- $\gamma$ juga merangsang produksi isotipe imunoglobulin oleh limfosit B, misalnya IgG2 pada manusia, yang mengaktifkan komplemen dan melapisi (opsonisasi) bakteri, meningkatkan fungsi makrofag (Kresno, 2001).

Dalam penelitian ini digunakan PSK yang memiliki bahan aktif berupa $\beta$-glukan sebagai bahan imuno-potensiasi yang diperoleh dari jamur Coriolus versicolor. Pemberian PSK dilakukan sebelum dan atau sesudah paparan M. tuberculosis.

Menurut Hong et al. (2004), $\beta$-glukan yang masuk tubuh secara oral memiliki resistensi terhadap asam sehingga bila masuk ke dalam lambung strukturnya tidak akan berubah. $\beta$-glukan yang ada dalam usus akan melakukan kontak dengan makrofag yang ada pada dinding usus dibantu oleh sel M (microfold) yaitu sel yang terspesialisasi dan terdapat pada ileum. Sel M akan mengambil $\beta$-glukan melalui pinositosis dan membawanya melalui dinding usus di mana beberapa sel seperti makrofag, sel T, sel B dan sel imun lainnya menunggu. Selanjutnya $\beta$-glukan yang difagosit oleh makrofag akan didegradasi menjadi fragmen-fragmen, lalu diangkut menuju sumsum tulang di mana fragmenfragmen $\beta$-glukan hasil degradasi akan dilepaskan. Menurut Chi-Fung et al., (2009), fragmen-fragmen ini dikeluarkan keluar sel makrofag dan ditangkap oleh reseptor komplemen (CR3) yang berada pada permukaan sel granulosit, monosit, dan sel dendritik. Sel-sel ini dengan antibodi kemudian teraktivasi dan dapat membunuh sel tumor ataupun sel berbahaya lain. Dengan mekanisme yang terdapat pada datadata dalam penelitian terakhir, $\beta$-glukan adalah senyawa yang dapat digunakan sebagai imunomodulator pada sistem imun spesifik dan sistem imun non spesifik. Kemampuan senyawa aktif dalam sistem imun spesifik adalah mengenali dengan cepat dan merespons penyebaran bakteri.

Beta ( $\beta$ )-glukan akan berikatan dengan makrofag pada reseptor CR3 yang merupakan reseptor gabungan di mana mempunyai dua daerah pengikat. Daerah pertama bertanggung jawab untuk mengikat jenis komplemen, yang larut protein darah dikenal sebagai C3 (atau iC3b). C3 akan melekat pada antibodi spesifik yang kemudian berikatan dengan patogen yang ditargetkan kemudian mengopsoninnya. Daerah kedua pada reseptor CR3 mengikat ke karbohidrat pada sel-sel ragi atau jamur yang memungkinkan makrofag untuk mengenali jamur sebagai "nonself" (Hong et al., 2004). Dengan adanya sinyal kedua ikatan tersebut membantu proses fagositosis makrofag terhadap infeksi tuberkulosis.
Dari hasil peneltian ini terlihat bahwa pada kelompok $\mathrm{K}$ dan $\mathrm{K}+$ tidak berbeda signifikan tetapi berbeda dengan kelompok K-, P1, P2 dan P3. Hal ini disebabkan karena mencit $\mathrm{K}$ dan $\mathrm{K}+$ sebelumnya tidak dipapar dengan antigen M. tuberculosis, yang artinya tidak ada kontak sebelumnya dengan antigen sehingga tidak terdapat antibodi spesifik. Hal ini didukung oleh Kresno (2001) bahwa setiap klon limfosit diprogramkan untuk memproduksi satu jenis antibodi spesifik terhadap antigen tertentu. Reaksi warna yang terjadi kemungkinan karena adanya antibodi natural dalam tubuh mencit yang konsentrasinya rendah.

Dari hasil penelitian ini terlihat bahwa pada kelompok K-, P1 dan P2 dapat meningkatkan respons imun berupa pembentukan antibodi yang secara signifikan lebih tinggi bila dibandingkan dengan kelompok $\mathrm{K}$ dan $\mathrm{K}+$. Hal ini menunjukkan bahwa M. tuberculosis adalah imunogen yang kuat yang mampu menginduksi pembentukan antibodi yang spesifik untuk bakteri tersebut. Komponen yang terkandung pada dinding sel bakteri yang menjadi penentu antigenitas yang kuat (Todar, 2005). Antigen M. tuberculosis yang dipaparkan secara intraperitonial akan diikat oleh makrofag. Pernyataan ini didukung oleh Baratawidjaya (2006) bahwa makrofag bertindak sebagai antigen precenting cell (APC) yang menyajikan molekul imunogen ke permukaan sel sehingga dikenali oleh sel T helper yang mengaktifkan sel $B$ untuk berdiferensiasi menjadi sel plasma dan sel memori. Sel plasma kemudian menghasilkan antibodi dan sel B memori berfungsi untuk merekam imunogen yang telah dikenali. Pada kelompok P1 dan P2 tidak terdapat perbedaan yang signifikan. Hal ini diduga antigenitas M. tuberculosis masih sangat kuat sehingga pemberian PSK dengan waktu pemberian sebelum atau sesudah paparan M. tuberculosis tidak berpengaruh dalam meningkatkan pembentukan antibodi guna memerangi bakteri tersebut. Sedangkan kelompok K-, P1 dan P2 berbeda signifikan dengan kelompok P3. Kelompok P3 menunjukkan perbedaan yang signifikan dibandingkan dengan seluruh kelompok perlakuan. Hal ini menunjukkan bahwa pemberian PSK dengan dua kali waktu pemberian yaitu sebelum dan sesudah paparan M. tuberculosis berpengaruh terhadap peningkatan antibodi yang terbentuk.

Pada kelompok P1, P2 dan P3 diketahui mampu meningkatkan rerata nilai OD antibodi yang terbentuk hingga melebihi kelompok $\mathrm{K}$ dan $\mathrm{K}+$. Sementara itu, kelompok perlakuan $\mathrm{P} 3$ mampu meningkatkan rerata nilai OD antibodi yang terbentuk hingga melebihi kelompok K-. Oleh karena itu, dalam penelitian ini dapat disimpulkan bahwa pemberian PSK sebelum dan sesudah pemaparan 
M. tuberculosis paling efektif dalam meningkatkan pembentukan antibodi akibat paparan M. tuberculosis. Pemberian PSK sebelum paparan M. tuberculosis dapat berfungsi sebagai pencegahan (preventif) yaitu mendorong pembentukan antibodi sehingga antibodi yang semakin menurun pada penderita TB tidak terlalu drastis dan bisa diatasi dengan diberikannya kembali PSK sebagai pengobatan (kuratif) terhadap M. tuberculosis untuk mendorong pembentukan lebih banyak antibodi. Hal ini didukung oleh pernyataan Pietro (2003) bahwa $\beta$-glukan lebih efektif untuk pencegahan dan pengobatan terhadap penyakit yang berhubungan dengan ketahanan sistem imun tubuh.

Kesimpulan dari penelitian ini adalah: (1) pemberian PSK berpengaruh terhadap pembentukan antibodi mencit akibat paparan M. tuberculosis, (2) perbedaan waktu pemberian PSK berpengaruh terhadap pembentukan antibodi mencit. Waktu pemberian PSK sebelum dan sesudah paparan M. tuberculosis lebih optimum untuk pembentukan antibodi.

\section{UCAPAN TERIMA KASIH}

Penelitian adalah hasil dari Penelitian Strategis Nasional melalui dana DIPA Unair tahun 2009 dengan judul 'Bioaktivitas polisakarida krestin dari ekstrak jamur Coriolus versicolor sebagai imunomodulator respons imun akibat infeksi M. tuberculosis'.

\section{KEPUSTAKAAN}

Alsagaff, H., dan Mukty, A. 2002. Dasar-Dasar Ilmu Penyakit Paru, Airlangga University Press, Surabaya.

Artama, W.T. 1992, Antibodi Monoklonal: Teori, Produksi, Karakterisasi dan Penerapan, PAU-Bioteknologi, Universitas Gadjah Mada, Yogyakarta.

Baratawidjaja, K.G. 2006, Imunologi Dasar, Edisi Ketujuh, Fakultas Kedokteran Universitas Indonesia, Jakarta.

Bellanti, JA. 1993, Imunologi III, edisi Bahasa Indonesia, Gadjah Mada University Press, Yogyakarta.

Burgess, GW. 1995, Teknologi ELISA: Dalam Dignosis dan Penelitian, Cetakan Pertama, Gadjah Mada University Press, Yogyakarta.

Chi-Fung, CG., Wing, KC., dan Daniel, M. 2009, The effects of $\beta$-Glucan on Human Immune and Cancer Cells, Journal Hematology Oncology, 2: 25.

Cui, J., dan Chisti, Y. 2003, Polisaccharopeptides of Coriolus versicolor Physiological Activity, Uses, and Production. Biotecnolology Advance, 109-122.

Cui, J., Goh, K.K.T., Archer, R., dan Sigh, H. 2007, Characterization and Bioactivity of Protein-bound Polysaccharides from Submerged-culture Fermentation of Coriolus versicolor $\mathrm{Wr}$ -
74 ATCC-20545 Strains, Journal Industrial Microbiology Biotechnology, 34: 393-402.

Crowther, JR. 1995, ELISA: Theory and Practice, Humana Press, New Jersey.

Dzen, SM., Roekistiningsih, S., Sanarto, dan Sri, W. 2003, Bakteriologi Medik, Bayumedia Publishing, Malang

Guyton, A.C., dan Hall, J.E. 1997, Buku Ajar Fisiologi Kedokteran, alih bahasa oleh Setiawan, I., Tengadi, K. A., dan Santoso, Edisi 9, Penerbit Buku Kedokteran EGC, Jakarta.

Hong, F., Jun, Y., Jarek, T.B., Daniel, J., Richard, D., Gary, R., Pei, X.X., Nai, K., Cheung, dan Ross, G.D. 2004, Mechanism by which Orally Administered Beta-1,3-Glucans Enhance The Tumoricidal Activity of Antitumor Monoclonal Antibodies in Murine Tumor Models, Journal Immunology, 173: 797-806.

Howard, G.C., Delia, R., dan Bethel. 2001, Basic Methods in Antibody Production and Characterization, CRC Press, USA.

Koendhori, E.B. 2008, Peran Ethanol Extract Propolis Terhadap Produksi Interferon $\gamma$, Interleukin 10 dan Transforming Growth Factor $\beta 1$ serta Kerusakan Jaringan Paru Pada Mencit Yang Diinfeksi Dengan Mycobacterium tuberculosis, Disertasi, Program Pasca Sarjana, Universitas Airlangga, Surabaya.

Kresno, S.B. 2001, Imunologi: Diagnosa dan Prosedur Laboratorium, Edisi IV, Cetakan Ke 1 (Dengan Perbaikan), Balai Penelitian FKNI, Jakarta.

Ooi, V.E., dan Liu, F. 2000, A Review of Pharmacological Activities of Mushroom Polysaccharides. International Journal Medicinal Mushroom: 196-206.

Pietro, P. 2003. Composition for Preventif and/or Treatment of Lipid Metabolism Disorders and Allergic Form. http:// freepatent online.com.

Poeloengan, M., Komala, I., dan Noor, S.M. 2009. Bahaya dan Penanganan Tuberculosis, Lokakarya Nasional Penyakit Zoonosis, Balai Penelitian Veteriner, Bogor.

Sastroasmoro, S., Santoso, S., Samsuridjal, D., Ratna, M., Wuwuh, U.N., Monalisa, N., Mutiara, A., dan Nastiti, R.,2004, Pemberian terapi imunomodulator herbal. Himpunan Tanaman Obat Indonesia.

Suwarno, Sianita, N., Rahmahani, J., Rahardjo, A.P., Rantam, F.A., dan Ernawati, R. 2008, ELISA Teori dan Protokol, Departemen Mikrobiologi Fakultas Kedokteran Hewan Unair, Surabaya.

Todar, K. 2005, Todar's Online Textbook of Bacteriology, University of Wisconsin-Madison Department of Bacteriology.

Tsukagoshi, S., Hashimoto, Y., Fujii, G., Kobayashi, H., Nomoto, K., dan Orita, K. 1984, Krestin (PSK). Cancer Treatment Reviews, 1984, 11: 131-155.

Vetvicka, V., Kiyomi, T., Rosemade, M., Paulin, B., Bill, K., dan Gary, O. 2002, Orally-Administered Yeast $\beta-1,3$ glucan Prophylactically Protects Against Anthrax Infection and Cancer in Mice, Journal American Nutraceutical Assosiation, 5: 2. 
Wahyuningsih, S.P.A., Hayati, A., dan Mustofa, I. 2007, Pembakuan Epitop Protein Membran Spermatozoa Kelinci sebagai Dasar Pengembangan Imunokontrasepsi pada Pria. Laporan Penelitian. Lembaga Penelitian Universitas Airlangga, Surabaya.
Zhou, X., H. Jiang, Lin, J., dan Tang, K. 2007, Cytotoxic activities of Coriolus versicolor (Yunzhi) extracts on human liver cancer and breast cancer cell line, National Library of Medicine, Current Medical Chemistry. 